\title{
Analisis Perbedaan Partisipasi Suami dan Tenaga Kesehatan terhadap Tingkat Kecemasan Ibu Intrapartum Primipara
}

\author{
Siti Khotimah ${ }^{1}$, Evin Noviana Sari ${ }^{1}$ \\ ${ }^{1}$ Dosen Program Studi D3 Kebidanan Universitas Dharmas Indonesia \\ Corresponding author: Siti Khotimah (sitikhotimah900@gmail.com)
}

Received 22 September 2018; Accepted 22 September 2018; Published 24 September 2018

\begin{abstract}
Childbirth is a fairly heavy period for mothers, where the birth process is like a mother's life and death stakes, especially in primiparous mothers, where they do not have the experience of giving birth. Psychological support and attention will have an impact on social life patterns of harmony, respect, sacrifice, compassion and empathy during the delivery process and from the technical aspects, can reduce aspects of resources such as: experts, normal delivery methods, acceleration, pain control and care neonatal. The presence of a companion childbirth is one of the moral support needed, because at this time the mother is experiencing severe stress. This study aims to determine the significant differences between the participation of husbands and health workers towards the level of anxiety of primiparous intrapartum mothers. In this study, the author uses a quasi experiment design with the form of a Post Test only Control Group Design. Respondents in this study were primiparous intraparum mothers who were in the Sitiung 1 health center area of Dharmasraya Regency as many as 76 people with positive sampling technique. The research test used was Wilcoxon with the Mann-Whitney method analysis. Based on the results of the study found that there is an influence of husband's participation on the level of primipara intrapartum maternal anxiety with $\mathrm{p}$ value of 0.027 and there is an influence of participation on the level of primiparous mother's intrapartum anxiety $\mathrm{p}$ value 0.004 so it can be concluded that there is a significant difference between the participation of husband and health personnel to anxiety level primipara intrapartum mother.
\end{abstract}

Keywords: Husband's participation, participation of health workers, anxiety levels of mother intrapartum primipara

Copyright $\odot 2018$ STIKes Surya Mitra Husada

All rights reserved.

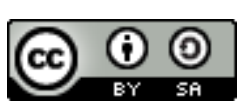

This is an open-acces article distributed under the terms of the Creative Commons Attribution-ShareAlike 4.0 International License.

\section{PENDAHULUAN}

Dewasa ini angka kematian ibu dan kematian bayi di Indonesia masih tinggi dan upaya penanggulanganya cukup rumit. Oleh karena itu Angka Kematian Ibu (AKI) dan Angka Kematian Bayi (AKB) di Indonesia masih merupakan masalah kesehatan masyarakat. Berdasarkan Survei Demogravi Kesehatan Indonesia (SDKI) tahun 2007 didapatkan AKI sebesar 228/100.000 kelahiran 
hidup, mengalami penurunan jika dibandingkan dengan AKI tahun 2002 yaitu 307/100.000 kelahiran hidup. Data AKI tersebut membuat Indonesia mulai optimis bahwa target MDGs untuk AKI tahun 2015 adalah sebesar 102/100.000 kelahiran hidup dapat tercapai. Akan tetapi, optimisme tersebut berubah menjadi kecemasan setelah melihat hasil SDKI tahun 2012 bahwa AKI mengalami kenaikan signifikan sebesar 359/100.000 kelahiran hidup (Depkes RI, 2012).

Lima penyebab kematian ibu terbesar yaitu perdarahan, hipertensi dalam kehamilan (HDK), infeksi, partus lama/macet, dan abortus. Kematian ibu di Indonesia masih didominasi oleh tiga penyebab utama kematian yaitu perdarahan, hipertensi dalam kehamilan dan infeksi. Pada tahun 2013 jumlah AKI disebabkan oleh perdarahan sebesar 30,3\%, HDK sebesar 27,1\% dan infeksi sebesar 7,3\% dan penyebab lain sebesar 40,8\% (Kemenkes RI, 2016).

Kehamilan termasuk salah satu periode krisis dalam kehidupan perempuan. Situasi ini menimbulkan perubahan drastis yaitu fisik dan psikologis. Dalam aspek psikologis, timbul pengharapan yang disertai kecemasan menyambut persiapan kedatangan bayi. Semuanya itu mewarnai interaksi antara isteri dan suaminya (Amelia, 2006).

Peran suami dalam upaya meningkatkan kesehatan ibu selama hamil sangat diperlukan terutama dalam hal pemberian dukungan kepada istri untuk mendapatkan pelayanan antenatal yang baik serta mengantar dan mendampingi istri melakukan pemeriksaan kepada tenaga kesehatan terkait kesehatan ibu sehingga secara tidak langsung suami dapat belajar tentang tanda bahaya kehamilan bahkan kebutuhan ibu selama dan saat proses persalinan berlangsung (BKKBN, 2008).

Kehadiran pendamping persalinan merupakan salah satu dukungan moral yang dibutuhkan, karena pada saat ini ibu sedang mengalami stress yang berat sekali. Walaupun faktor tunggal terbesar yang dapat memodifikasi proses persalinan dan kelahiran dalam kebudayaan kita adalah para personil medis, akan tetapi dukungan suami juga merupakan salah satu faktor yang turut berperan penting dalam menentukan status kesehatan ibu yang dapat berpengaruh besar terhadap bentuk kecemasan dan depresi yang dirasakan ibu selama dan sesudah persalinan (Pelita, 2002).

Perhatian yang didapat seorang ibu pada masa persalinan akan terus dikenang oleh ibu terutama bagi mereka yang pertama kali melahirkan dan dapat menjadi modal lancarnya persalinan serta membuat ibu menjadi merasa aman dan tidak takut menghadapi persalinan (Fitriyani, 2006).

Mengikutsertakan suami dan keluarga selama proses persalinan dan kelahiran bayi merupakan beberapa prinsip dasar asuhan sayang ibu. Banyak hasil penelitian menunjukkan bahwa jika para ibu diperhatikan dan diberi dukungan selama persalinan dan kelahiran bayi serta mengetahui dengan baik mengenai proses persalinan dan asuhan yang akan mereka terima, mereka akan mendapatkan rasa aman dan hasil yang lebih baik. Disebutkan pula bahwa hal tersebut diatas dapat mengurangi terjadinya persalinan dengan vakum, cunam, dan sectio sesar, dan persalinan berlangsung lebih cepat sehingga dapat mengurangi faktor risiko terjadinya perdarahan sebagai penyebab langsung AKI di Indonesia (Enkim, Et Al, 2000).

Atas alasan tersebut, penulis merasa perlu untuk melakukan penelitian terkait perbedaan pasrtisipasi suami dan tenaga kesehatan terhadap tingkat kecemasan ibu intrapartum sebab proses persalinan yang tenang tanpa kecemasan berlebihan akan sangat berpengaruh terhadap kualitas tumbuh kembang bayi pada masa perinatal, bahkan sampai masa balita dan usia sekolah.

Penelitian ini diharapkan dapat memberikan gambaran yang tepat dari perbedaan antara pemberian partisipasi yang lebih dibutuhkan untuk ibu intrapartum dalam menghadapi persalinan, baik dari suami maupun dari tenaga kesehatan guna untuk membantu menurunkan tingkat kecemasan.

\section{METODE}

Penelitian ini merupakan jenis penelitian kuantitatif dengan quasi eksperimen dengan bentuk rangcangan non-equivalent posstest-only control group design Responden dalam penelitian ini adalah ibu intrapartum primipara yang berada di lingkungan puskesmas Sitiung 1 Kabupaten Dharmasraya. Pada penelitian ini terdapat dua perlakuan yaitu partisipasi suami dan partisipasi tenaga kesehatan yang mana setelah perlakuan selesai maka akan dilakukan pengukuran pada efek tingkat kecemasan intrapartumnya dengan cara observasi langsung menggunakan kuesioner. Besar sampel dalam penelitian ini menggunakan dua kelompok eksperimen (kelompok partisipasi suami dan kelompok 
partisipasi tenaga kesehatan) yang masing-masing kelompok terdiri dari 38 orang maka jumlah responden sebanyak 76 orang. Teknik yang digunakan dalam pengambilan sampel adalah porposive sampling. Uji penelitian yang digunakan untuk menghitung adalah Wilcoxon dan kemudian dilanjutkan dengan analisis metode Mann-Whitney dengan uji t tidak berpasangan. Waktu penelitian dilakukan pada bulan Juli tahun 2018.

\section{HASIL PENELITIAN}

\section{Distribusi Frekuensi Pengetahuan Sebelum}

Tabel 1. Distribusi Frekuensi Partisipasi Suami dan Partisipasi Tenaga Kesehatan Terhadap Tingkat Kecemasan Ibu Intrapartum Primipara

\begin{tabular}{lcccc}
\hline & \multicolumn{2}{c}{ Partisipasi Suami } & \multicolumn{2}{c}{ Partisipasi Tenaga Kesehatan } \\
\cline { 2 - 5 } & Frekuensi & Persentase $(\%)$ & Frekuensi & Persentase $(\%)$ \\
\hline Baik & 10 & 26,31 & 18 & 47,37 \\
\hline Cukup & 11 & 28,95 & 14 & 36,84 \\
\hline Kurang & 17 & 44,74 & 6 & 15,79 \\
\hline Jumlah & 38 & 100 & 38 & 100 \\
\hline
\end{tabular}

Berdasarkan tabel 1 dapat diketahui bahwa sama-sama hampir setengahnya dari responden pada kelompok partisipasi suami menunjukkan partisipasi kurang yaitu sebanyak 17 orang $(44,74 \%)$ dan pada kelompok partisipasi tenaga kesehatan menunjukkan partisipasi baik yaitu sebanyak 18 orang $(47,37 \%)$.

\section{Distribusi Frekuensi Sesudah}

Tabel 2. Distribusi Frekuensi Tingkat Kecemasan Ibu Intrapartum Primipara pada Kelompok Partisipasi suami dan Kelompok Partisipasi Tenaga Kesehatan

\begin{tabular}{lcccc}
\hline & \multicolumn{2}{c}{$\begin{array}{c}\text { Tingkat Kecemasan Ibu } \\
\text { Intrapartum Primipara Partisipasi } \\
\text { Suami }\end{array}$} & $\begin{array}{c}\text { Tingkat Kecemasan Ibu Intrapartum } \\
\text { Primipara Partisipasi Tenaga Kesehatan }\end{array}$ \\
\cline { 2 - 5 } & Frekuensi & Persentase (\%) & Frekuensi & Persentase (\%) \\
\hline Ringan & 9 & 23,68 & 16 & 42,11 \\
\hline Sedang & 13 & 34,21 & 13 & 34,21 \\
\hline Berat & 16 & 42,11 & 9 & 23,68 \\
\hline Jumlah & 38 & 100 & 38 & 100 \\
\hline
\end{tabular}

Berdasarkan tabel 2 dapat diketahui bahwa sama-sama hampir setengahnya dari responden pada kelompok partisipasi suami menunjukkan tingkat kecemasan berat yaitu sebanyak 16 orang $(42,11 \%)$ dan pada kelompok partisipasi tenaga kesehatan menunjukkan tingkat kecemasan ringan yaitu sebanyak 16 orang $(42,11 \%)$. 
Tabel 3. Pengaruh Partisipasi Suami terhadap Tingkat Kecemasan Ibu Intrapartum Primipara

\begin{tabular}{|c|c|c|c|c|c|}
\hline & \multicolumn{3}{|c|}{ Tingkat Kecemasan Ibu Intrapartum Primipara } & \multirow[t]{2}{*}{ Total } \\
\hline & & Ringan & Sedang & Berat & \\
\hline \multirow{6}{*}{$\begin{array}{l}\text { Partisipasi } \\
\text { Suami }\end{array}$} & \multirow[t]{2}{*}{ Baik } & 4 & 5 & 1 & 10 \\
\hline & & $40,0 \%$ & $50,0 \%$ & $10,0 \%$ & $100,0 \%$ \\
\hline & \multirow{2}{*}{ Cukup } & 3 & 5 & 3 & 11 \\
\hline & & $27,3 \%$ & $45,5 \%$ & $27,3 \%$ & $100,0 \%$ \\
\hline & \multirow[b]{2}{*}{ Kurang } & 2 & 3 & 12 & 17 \\
\hline & & $11,8 \%$ & $17,6 \%$ & $70,6 \%$ & $100,0 \%$ \\
\hline \multirow[t]{2}{*}{ Total } & & 9 & 13 & 16 & 38 \\
\hline & & $23,7 \%$ & $34,2 \%$ & $42,1 \%$ & $100,0 \%$ \\
\hline
\end{tabular}

Nilai P Value $=0,027$

Berdasarkan tabel 3 dapat diketahui bahwa terdapat pengaruh partisipasi suami terhadap tingkat kecemasan ibu intrapartum primipara dengan nilai $p$ value $=0,027$.

Tabel 4. Pengaruh Partisipasi Tenaga Kesehatan Terhadap Tingkat Kecemasan Ibu Intrapartum Primipara

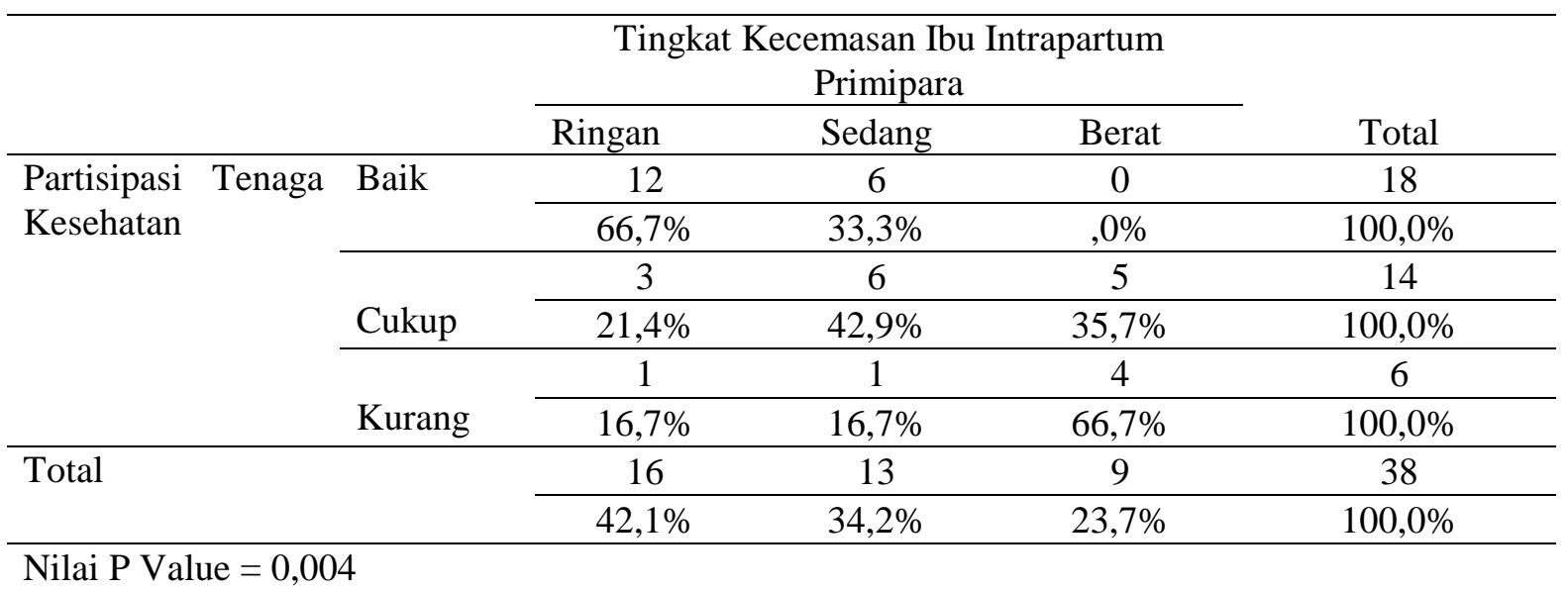

Berdasarkan tabel 4 dapat diketahui bahwa terdapat pengaruh partisipasi tenaga kesehatan terhadap tingkat kecemasan ibu intrapartum primipara dengan nilai $\mathrm{p}$ value $=0,004$.

Tabel 5. Analisis Perbedaan Partisipasi Suami dan Partisipasi Tenaga Kesehatan terhadap Tingkat Kecemasan Ibu Intrapartum Primipara

\begin{tabular}{|c|c|c|c|c|c|}
\hline & & Kelompok & $\mathrm{N}$ & Mean Rank & Sum of Ranks \\
\hline \multirow{3}{*}{$\begin{array}{l}\text { Tingkat } \\
\text { Ibu } \\
\text { Primipara }\end{array}$} & \multirow{3}{*}{$\begin{array}{l}\text { Kecemasan } \\
\text { Intrapartum }\end{array}$} & Partisipasi Suami & 38 & 43,20 & 1641,50 \\
\hline & & Kesehatan & 38 & 33,80 & 1284,50 \\
\hline & & Total & 76 & \multicolumn{2}{|c|}{ Nilai P Value $=0,049$} \\
\hline
\end{tabular}

Berdasarkan tabel 5 dapat diketahui bahwa terdapat perbedaan yang signifikan antara partisipasi suami dan partisipasi tenaga kesehatan terhadap tingkat kecemasan ibu intrapartum primipara dengan nilai $\mathrm{p}$ value $=0,049$. 


\section{PEMBAHASAN}

Berdasarkan hasil penelitian pada tabel 1 dapat diketahui bahwa hampir setangahnya dari partisipasi suami menunjukkan partisipasi kurang yaitu sebanyak 44,74\%, sedangkan partisipasi tenaga kesehatan menunjukkan partisipasi baik yaitu sebanyak 47,37\%, dan menurut Juwita (2014) dalam penelitianya tentang partisipasi suami didapatkan yaitu sebagian besar responden menunjukkan partisipasi baik selama proses persalinan dengan persentase $(93,6 \%)$.

Mardikanto (2003) mengatakan bahwa partisipasi adalah keikutsertaan seseorang atau sekelompok anggota masyarakat dalam suatu kegiatan. Partisipasi dalam kesehatan reproduksi adalah tanggung jawab pria dalam kesehatan reproduksi terutama dalam pemeliharaan kesehatan dan kelangsungan hidup ibu dan anak, serta berperilaku seksual yang sehat dan aman bagi dirinya, istri dan keluarganya. Asuhan Kehamilan merupakan salah satu bentuk dari upaya pemeliharaan reproduksi. Pengertian partisipasi suami terhadap kehamilan isteri secara khusus belum ditemukan.

Menurut Cholil et all (1998) beberapa faktor yang mempengaruhi partisipasi suami dalam perlindungan kesehatan reproduksi istri (ibu) adalah: 1). Budaya, diberbagai wilayah Indonesia terutama didalam masyarakat yang masih tradisional (patrilineal) menganggap bahwa kaum pria tidak sederajat dengan kaum wanita, dan wanita hanyalah bertugas untuk melayani kebutuhan dan keinginan suami saja. Anggapan seperti ini mempengaruhi perlakuan suami terhadap kesehatan reproduksi istri, misal: kualitas dan kuantitas makanan yang lebih baik dibanding istri maupun anak karena menganggap suamilah yang mencari nafkah dan sebagai kepala rumah tangga sehingga asupan zat gizi mikro untuk istri kurang, suami tidak empati atau peduli dengan keadaan ibu yang sedang hamil maupun menyusui anak dan lain-lain. Beberapa cara merubah budaya di atas antara lain: a]. Persepsi mengenai kesetaraan gender perlu diberikan dan disosialisasikan sejak dini melalui kegiatan formal (sekolah) maupun non formal (kelompok masyarakat), dan diaplikasikan ke dalam praktek kehidupan sehari-hari; b]. Penyuluhan pada sarana maupun tempat dimana pria sering berkumpul dan berinteraksi (misalnya tempat kerja. Club, tukang cukur, dll); c]. Berikan informasi sesering mungkin dengan stimulus yang menarik perhatian; d]. Masyarakat Indonesia pada umumnya masih mempunyai perasaan malu dan sungkan kepada lingkungan sekitar, oleh karena itu pada pelaksanaan Gerakan Sayang Ibu (GSI) perlu dipikirkan sesuatu atau kegiatan yang dapat memotivasi kepala keluarga untuk segera merealisasikan kepeduliannya kepada istri; 2). Pendapatan, pada masyarakat kebanyakan, $75 \%-100 \%$ penghasilannya dipergunakan untuk membiayai keperluan hidupnya bahkan banyak keluarga yang setiap bulan bersaldo rendah. Sehingga pada akhirnya ibu hamil tidak diperiksakan ke pelayanan kesehatan karena tidak mempunyai kemampuan untuk membayar. Secara konkrit dapat dikemukakan bahwa pemberdayaan suami perlu dikaitkan dengan pemberdayaan ekonomi keluarga sehingga kepala keluarga tidak mempunyai alasan untuk tidak memperhatikan kesehatan istrinya karena permasalahan keuangan; 3). Tingkat Pendidikan, tingkat pendidikan akan mempengaruhi wawasan dan pengetahuan suami sebagai kepala rumah tangga. Semakin rendah pengetahuan suami maka akses terhadap informasi kesehatan istrinya semakin berkurang sehingga suami akan kesulitan mengambil keputusan secara efektif. Akhirnya, pandangan baru yang perlu diperkenalkan dan lebih dispesialisasikan kembali untuk memberdayakan kaum suami mendasarkan pada pengertian bahwa: a]. Suami memainkan peranan yang sangat penting, terutama dalam pengambilan keputusan berkenaan dengan kesehatan reproduksi pasangannya; b]. Suami sangat berkepentingan terhadap kesehatan reproduksi pasangannya; c]. Saling pengertian serta kesetimbangan peranan antara kedua pasangan dapat membantu meningkatkan perilaku yang kondusif terhadap peningkatan kesehatan reproduksi; d]. Pasangan yang selalu berkomunikasi tentang perencanaan keluarga maupun kesehatan reproduksi yang satu dengan yang lainnya akan mendapatkan keputusan yang lebih efektif dan lebih baik.

Berdasarkan hasil penelitian pada tabel 2 dapat diketahui bahwa sama-sama hampir setengahnya dari responden pada kelompok partisipasi suami menunjukkan tingkat kecemasan berat yaitu sebanyak $42,11 \%$ dan pada kelompok partisipasi tenaga kesehatan menunjukkan tingkat kecemasan ringan yaitu sebanyak $42,11 \%$.

Menurut Stwart dan Sudden tingkat kecemasan diklasifikasikan menjadi 4 tingkatan yaitu: 1). Kecemasan ringan yaitu kecemasan ini berhubungan dengan ketegangan dalam kehidupan sehari-hari 
dan menyebabkan seseorang menjadi waspada; 2). Kecemasan sedang yaitu kecemasan sedang memungkinkan seseorang untuk memusatkan pada hal yang penting dan mengesampingkan yang lain, karena itu seseorang mengalami perhatian yang selektif namun dapat melakukan sesuatu yang lebih terarah; 3).Kecemasan berat yaitu kecemasan berat termasuk tingkat kecemasan yang tinggi karena sudah terjadi stress dalam diri seseorang, tingkatan ini sangat mengurangi lahan persepsi seseorang. Seseorang cenderung untuk memusatkan pada sesuatu yang terinci, spesifik, dan tidak dapat berpikir tentang hal lain. Semua perilaku ditujukan untuk mengurangi ketegangan orang tersebut memerlukan banyak pengarahan untuk memusatkan pada suatu area lain; 4). Tingkat panik yaitu berhubungan dengan ketakutan dan terror. Karena mengalami kehilangan kendali, orang yang mengalami panik tidak mampu melakukan sesuatu walaupun dengan pengarahan.

Berdasarkan hasil penelitian pada tabel 5 didapatkan bahwa terdapat perbedaan yang signifikan antara partisipasi suami dan partisipasi tenaga kesehatan terhadap tingkat kecemasan ibu intrapartum primipara dengan nilai $\mathrm{p}$ value $=0,049$.

Menurut Mardikanto (2003) dikatakan untuk menggerakkan partisipasi masyarakat dibutuhkan kemampuan untuk melaksanakan sesuatu dimana sangat dipengaruhi oleh tingkat pendidikan dan keterampilan yang dimilikinya. Dalam hal ini dikemukakan kegiatan yang menunjukkan partisipasi salahsatunya adalah partisipasi dalam pengambilan keputusan.

Terdapat 3 faktor yang mempengaruhi kecemasan antara lain: 1). Status ekonomi yaitu tingkat keadaan ekonomi yang diukur dari jumlah total penghasilan. Salah satu faktor yang dapat ditimbulkan kecemasan adalah stress psikososial; 2).Tingkat pendidikan yaitu tingkat pendidikan merupakan salah satu faktor yang mempengaruhi kecemasan dalam kesiapan menghadapi persalinan. Selain itu faktor informasi dan pengalaman akan menambah pengetahuan tentang sesuatu yang bersifat non formal. Pendidikan yang rendah akan menyebabkan seseorang mudah mengalami stress disebabkan kurangnya informasi; 3). Lingkungan yaitu lingkungan telah ditekankan pada dukungan sosial baik dukungan sosial dari suami ataupun keluarga, teman dan kerabat. Orang-orang dengan dukungan sosial tinggi dapat memiliki penghargaan diri lebih tinggi, yang membuat tidak mudah diserang stress.

Menurut Walyani (2015), kebutuhan dasar ibu dalam proses persalinan meliputi: 1). Dukungan fisik dan psikologis, setiap ibu yang akan memasuki masa persalinan maka muncul perasaan takut, khawatir ataupun cemas terutama pada ibu primipara. Perasaan takut akan meningkatkan rasa nyeri, otot-otot menjadi tegang dan ibu menjadi cepat lelah akibatnya akan menghambat persalinan. Ada 5 kebutuhan dasar bagi ibu bersalin, yaitu: a]. asuhan fisik dan psikologis; b]. Kehadiran seorang pendamping secara terus menerus; c]. Penerimaan atas sikap dan perilaku ibu; d]. Informasi tentang kemajuan persalinan dan persalinan yang aman; 2). Kebutuhan makanan dan cairan, makanan padat tidak boleh di berikan selama persalinan aktif, karena makanan padat lebih lama tinggal di lambung dari pada makanan cair, sehingga proses pencernaan lebih lambat selama proses persalinan. Selama proses persalinan, berikan ibu makan dan minum supaya ibu tidak kehilangan tenaga dan dehidrasi; 3). Kebutuhan Eliminasi, kandung kencing harus di kosongkan setiap 2 jam sekali selama proses persalinan. Bila pasien tidak dapat berkemih sendiri dapat di lakukan kateterisasi, karena kandung kemih yang penuh akan menghambat proses persalinan dan jika pasien merasa ingin buang air besar, kemungkinan adanya tanda dan gejala masuk kala II; 4). Posisi dan Aktifitas, posisi yang aman dan mempermudah proses persalinan, yaitu: a]. Duduk atau setengah duduk, lebih mudah bidan untuk membimbing kelahiran kepala bayi dan pengamatan perineum; b]. Posisi merangkak, baik untuk persalinan dengan punggung yang sakit, membantu bayi melakukan rotasi, dan peregangan minimal pada perineum; c]. Berjongkok atau berdiri, memperbesar ukuran panggul dan memperbesar dorongan untuk meneran; d]. Berbaring ke kiri, untuk memberi oksigenasi yang baik bagi bayi, mempercepat penurunan kepala bayi dan membantu mencegah terjadinya laserasi. Dalam proses bersalin anjurkan ibu untuk tidak terlentang dan miring ke kanan, karena akan menghambat oksigen dari plasenta ke janin. 


\section{KESIMPULAN}

Berdasarkan hasil penelitian didapatkan bahwa terdapat perbedaan yang signifikan antara partisipasi yang diberikan oleh suami dan partisipasi yang diberikan oleh tenaga kesehatan terhadap tingkat kecemasan ibu intrapartum primipara, dimana Partisipasi yang diberikan oleh tenaga kesehatan lebih baik untuk membantu menurunkan tingkat kecemasan yang dirasakan oleh ibu intrapartum primipara jika dibandingkan dengan partisipasi yang diberikan oleg suami.

\section{REFERENSI}

Hidayat, A.A.A. (2010). Metode Penelitian Kesehatan Paradigma Kuantitatif, Jakarta: Health Books

BKKBN. (2008). Modul Kesehatan Reproduksi Remaja, Yogyakarta: Badan Koordinasi Keluarga Berencana Nasional

Depkes RI. (2012). Profil Kesehatan Indonesia. Departemen Kesehatan Republik Indonesia

Freud, Sigmund. (2005). Pengantar Umum Psikoanalisis. Yogyakarta: Pustaka Pelajar

Juwita, S., \& Rahmah, H. (2014). Dukungan dan Partisipasi Suami saat Persalinan. Tersedia dari lib.ui.ac.id, Journal of public health and epidemiologi.

Kementrian RI. (2016). Profil Kesehatan Indonesia, tersedia di: http://www. Kemkes.go.id

Keumalahayati. (2008). Dukungan Suami Terhadap Kesiapan Ibu Primigravida Menghadapi Persalinan Di daerah Pedesaan Di Langsa Nangroe Aceh Darussalam. Tersedia di www.eprints.lib.ui.ac.id.

Pertiwi, D. (2011). Hubungan kehadiran suami sebagai pendamping istri bersalin terhadap penurunan rasa nyeri saat persalinan di klinik bersalin Sumiarini Medan. Tersedia di htttp//repository.usu.ac.id/bitstream/123456789/22991/6/cover.pdf

Prawirohardjo, S. (2013). Pelayanan kesehatan maternal dan neonatal. Jakarta: Bina pustaka

Purwaningsih, R. (2002). Hubungan antara pengetahuan dan sikap suami dengan dukungan terhadap kesehatan maternal istrinya di kelurahan Harapan Mulia. Jakarta Pusat

Manuaba, I.A.C, dkk. (2010). Ilmu Kebidanan, Penyakit Kandungan dan KB untuk Pendidik Bidan Edisi 2, Jakarta: EGC

Mardikanto. (2003). Partisipasi Siswa, Tersedia dari: http://turindraatp. blogspot.com

Notoatmodjo, S. (2009). Metodologi penelitian kesehatan edisi trevisi. Jakarta: Rineka Cipta

Rukiyah, A.Y., dkk. (2009). Asuhan Kebidanan I Kehamilan, Jakarta: Trans Info Media

Walyani, ES., \& Purwoastuti, E. (2015). Asuhan Kebidanan Persalinan dan Bayi Baru Lahir. Yogyakarta: pustaka baru press. 